\title{
ROS (Rekreasyonel Fırsat Dağılımı) Yöntemi ile Abant Tabiat Parkı'nda Kullanıcı Memnuniyetinin Belirlenmesi
}

\author{
Haldun MÜDERRISOĞLU ${ }^{1}$
}

\author{
Özgür YERLi ${ }^{1} \quad$ Aslı ALTANLAR TURAN ${ }^{1}$
}

Nurgül DURU ${ }^{1}$

Geliş Tarihi: 06.08.2005

\begin{abstract}
Öz: Bu çalışmanın amacı Abant Tabiat Parkı'ndaki rekreasyonel kullanımlara katılımları ve ROS (Rekreasyonel Fırsat Dağıımı) sınıflarındaki kriterlere göre saptanan alanları kullanan ziyaretçilerin memnuniyetlerindeki farkıııkları belirlemektir. Bunun yanında bu çalışma ile ROS sisteminin Abant Tabiat Parkı üzerinde kullanılabilirliği araştırımıştır. $\mathrm{Bu}$ amaçla 359 kişiye anket uygulanmıştır. Elde edilen verilerin yorumlanmasında korelasyon ve varyans analizinden yararlanılmıştır. Sonuç olarak Türkiye standartlarına göre ROS sistemi sınıflarının tekrar belirlenmesi, daha net standartlara oturtulması, ROS dilinin açıklanması ve kolay anlaşııılığının sağlanmasının gerektiği belirlenmiş, Abant Tabiat Parkı'nda genel memnuniyeti en çok etkileyen faktörlerin mevsim, grup büyüklügü, kullanıcıların cinsiyeti, yaşı, gelir düzeyi ve alana geldikleri yer olduğu tespit edilmiştir.
\end{abstract}

Anahtar Kelimeler: ROS (Rekreasyonel Fırsat Dağııımı), rekreasyon, kullanıcı memnuniyeti

\section{Determination of User Satisfaction in Abant Nature Park by Using ROS Method}

Abstract: The aim of this study is determining the participation in recreational activicies in Abant National Park and also the differences of the satisfaction of the visitors who use the areas chosen by ROS classes criterias. Besides adaptation of the ROS system to Abant Nature ark was researched. For his reason an inquiry was done to 359 people. Corelation and variance analyzes were used for interpreting the data taken. As a result it was found out that reestablishing the ROS class system according to Turkish standards, stabeling the system on clerarer standards, explaining the ROS language for easier understandingis needed. The most effective factors on general satisfaction in Abant Nature Park are, season, group size, visitor's gender, age, income level and the places they come from.

Key Words: ROS, recreation, user satisfaction

\section{Giriş}

Günümüz koşullarında doğal alanların korunması, üzerinde ciddiyetle düşünülmesi gereken bir durumdur. Bu intiyaçtan doğan bir sonuç olarak, doğal alanlardaki koruma ve rekreasyonel amaçlı kullanma dengesi ile ilgili çalışmalar için birçok yöntem geliştirilmiştir. Bu yöntemlerden biri de Rekreasyonel Fırsat Dağılımı'dır (Recreational Opportunity Spectrum - ROS). Bütün yöntemlerin temel amaçlarının başında rekreasyonel memnuniyet (recreational satisfaction) gelmektedir. Bu güne kadar yapılan birçok bilimsel çalışmada da rekreasyonel memnuniyet temel amaç olmuştur (Driver and Tocher 1970, Absher ve ark. 1996, Burns ve ark 1997). ROS, Amerika Birleşik Devletleri Orman Servisi (United States Forest Service) (USFS) tarafından, çoklu alan kullanımı ve kaynak yönetim planları içinde var olan karmaşayı çözmek amacıyla geliştirilmiştir. ROS kavramı ilk olarak Driver Brown ve arkadaşları tarafından ortaya konulurken (1978), 1980'de USFS tarafından planlama ve yönetim şekli Clark ve Stankey (1979)'in geliştirdiği şekliyle benimsenmiştir (Driver ve Brown 1978). ROS yöneticilere ve plancılara envanter oluşturmaya, hedef yönetim standartları tasarlamaya, alternatif yönetim faaliyetleri arasında karar vermeye, çoklu kullanım için rekreasyon kaynaklarının planlanmasında daha geniş bir içerik sağlamaya yardım etmek için bölgesel bir rekreasyon planlama aracı olarak tanımlanır (Brown ve ark. 1978; Driver \& Brown 1978, Clark \& Stankey 1979
Driver ve ark.1987, Dawson ve ark. 2001). Orijinal ROS envanter sistemi 6 alan sınıfını içermektedir: Primitif; yarıprimitif motorize olmayan; yarıprimitif motorize olan; yolu olan doğal; kırsal ve kentsel. Bu çalışmanın amacı Abant Tabiat Parkı'ndaki rekreasyonel kullanımlara katılımları ve ROS sınıflarındaki kriterlere göre saptanan alanları kullanan ziyaretçilerin memnuniyetlerindeki ve memnuniyetsizliklerindeki farklılıkları ve benzerlikleri belirlemektir. Bunun yanında bu çalışma ile ROS sisteminin Abant Tabiat Parkı üzerinde kullanılabilirliği de araştırılmıştır.

\section{Materyal ve Yöntem}

9 Ağustos 1983 tarih ve 2873 sayılı Milli Parklar Kanununun 23. maddesinin 2. fıkrası ile 21 Ekim 1988'de tabiat parkı olarak ilan edilen Abant Gölü ve çevresi, Batı Karadeniz bölgesinde Bolu ili merkez ilçesi Samat ve Örencik köyleri sınırları içerisinde yer almaktadır. Bolu'ya $33 \mathrm{~km}$. Ankara'ya $225 \mathrm{~km}$. İstanbul'a $258 \mathrm{~km}$. uzaklıkta olan Abant Tabiat Parkına, Ankara-İstanbul E-5 Devlet Karayolunun 203. km.sinden Ömerler Maden Suyu sapağıyla ayrılan $22 \mathrm{~km}$ lik yol ile ulaşılmaktadır (www.kultur.gov.tr). Abant Tabiat Parkı Bolu'nun $30 \mathrm{~km}$. güneybatısında $40^{\circ} 37^{\prime}$ kuzey ve $31^{\circ} 15^{\prime \prime}$ batı enlemleri arasındadır. 
Abant Gölü yeraltında meydana gelen tektonik çöküntüler sonucunda büyük taş bloklarının vadiyi doldurmasıyla oluşmuştur. Deniz seviyesinden yüksekliğ $1328 \mathrm{~m}$. yüzey genişliği $1.25 \mathrm{~km}^{2}$ olup maksimum $18 \mathrm{~m}$. derinliktedir. Tektonik kökenli göl Kuzey Anadolu fay hattında bulunmaktadır. Abant Gölü'nü dağlardan gelen kar suları ve bir iki küçük dere beslemektedir. Gölden dışarı taşan temiz ve doğal su Dirgene Çayı'dır (Atıcı ve Obalı 2002). Abant Gölü çevresinde sıralanan dağların zirveleri tabiat parkının sınırlarını oluşturmaktadır. Tabiat parkının en yüksek noktası 1794m. ile Erenler Tepesi iken en düşük noktası 1328m. ile Abant Gölü seviyesidir (OBM,1991). Abant gölü kış aylarındaki hızlı hava soğumaları nedeni ile kıyıdan başlayarak tamamen donmaktadır (Mater ve Sunay 1985).

Flora ve fauna bakımından oldukça zengin olan Abant Gölü ve çevresinde piknik, kamping, sportif olta balıkçılığı, yürüyüş, tekneyle, faytonla, atla gezinti kışın doğal buz pateni sıklıkla yapılan rekreatif aktivitelerdir. Ayrıca göl etrafında iki adet lüks otel, İ Özel İdaresine ait Göl Gazinosu, Devlet Konukevi ve Orman İaresine ait soysal tesisler bulunmaktadır (http://members.fortunecity.com).

Çalışma alanı olarak Abant Tabiat Parkı'nın seçilmesinin üç temel nedeni vardır. Bunlardan ilki alanın dört mevsim farklı rekreasyonel kullanımlara olanak vermesidir. İkincisi alanın günlük kullanıcı sayısının 4500 kişiye kadar çıkmasıdır. Sonuncusu ise Türkiye'nin en büyük metropolleri olan Ankara ve İstanbul'un etki alanında olması nedeni ile ziyaretçi profilindeki çeşitliliktir.

ROS Kullanılarak alanın kulanım karakteristiklerinin oluşturulması : Çalışma alanının ROS kapsamında incelenmesi ve belirlenen kriterlere göre değerlendirilmesi amacıyla, 7 ana başlık temel alınarak 7 adet harita hazırlanmış, hazırlanan bu haritaların çakıştırılması yolu ile sonuca ulaşılması metot olarak benimsenmiştir. Çalışma süresi boyunca haritaların hazırlanması ve çakıştırılması çalışmalarına yönelik AUTODESK AutoCAD 2000 ve ESRI ArcView GIS 3.3 programları kullanılmıştır.

ROS kapsamında çalışma alanının değerlendirilmesinde kullanılan ve her biri için haritalar oluşturulan 7 ana başlık şunlardır: Deneyim karakteristikleri, faaliyet tipleri, insan varlığı, konum karakteristikleri, sosyal konum, uzaklık, yönetsel konum.

Bu başlıklardan her biri için, Abant Tabiat Parkı'nın bir adet haritası oluşturulmuştur. Her bir harita oluşturulurken 6'şar adet alan özelliği dikkate alınmış ve çalışma alanının bu 6 alan özelliğinden hangisi ya da hangilerini bünyesinde barındırdığı ölçülmüştür. Deneyim karakteristikleri, faaliyet tipleri, insan varlığı, konum karakteristikleri, sosyal konum, uzaklık ve yönetsel konum başlıkları altında Abant Tabiat Parkı'nın primitif, yarı primitif motorize olmayan, yarı primitif motorize, yolu olan doğal, kırsal ve kentsel, alanlar içerip içermeği araştırılmış ve saptanmıştır (Şekil 1).

7 adet başlık ve her başlık için değerlendirilen 6 adet alan özelliği ile haritaların oluşturulmasının ardından, her bir alan özelliği için o alan özelliğini içeren bütün haritalar kendi içlerinde çakıştııılmıştır. Daha açık bir ifade ile "primitif" alanları içeren toplam 6 harita kendi içinde, "yarı primitif motorize olmayan" alanları içeren 6 harita kendi içinde, "yarı primitif motorize olan" alanları içeren 2 harita kendi içinde, "yolu olan doğal" alanları içeren 5 harita kendi içinde, "kırsal" alanları içeren 6 harita kendi içinde ve "kentsel" alanları içeren 5 harita kendi içinde çakıştırılmıştır. Sonuçta 6 yeni harita meydana gelmiştir. En son olarak ise ortaya çıkan bu 6 yeni harita birbirleri ile çakıştırılmıştır. Bu çakıştırma sonucunda çalışma alanı içerisinde yer alan hem kırsal hem de kentsel alanların ortak oldukları (kesiştikleri) alanlar sorgulanmıştır. Sorgulama sonucunda kırsal ve kentsel alanların kesiştikleri bölgeler; günübirlik piknik alanları, kamp alanları, otel-restoran-lokanta gibi binalardan birinin veya birkaçının bir arada bulundukları alanlar olarak tespit edilmiştir.

Çalışmanın bundan sonraki kısmı tespit edilen bu alanlardaki kullanıcı kitlesine, kullanıcı memnuniyetini ve memnuniyetsizliklerini ölçmek üzere hazırlanan anketlerin uygulaması aşaması ile gerçekleştirilmiştir.

Kullanıcı memnuniyetinin belirlenmesi : $\mathrm{Bu}$ çalışma kapsamında Abant Tabiat Parkı'na gelen ziyaretçilere, 15 dakikayı geçmeyen anketler uygulanmıştır. Bu anketlerin uygulanışı sırasında yüz yüze görüşme yöntemi kullanılmıştır. Çalışma alanı ROS kriterlerine bağlı olarak altı farklı alana ayrılmış ve bu anketler bu alanları kullanan ziyaretçilere yapılmıştır. Alandaki kullanıcı profilinin sosyo-demografik yapısını belirlemek amacıyla 4 soru çoktan seçmeli olarak hazırlanmıştır. Ziyaretçi grubunun çeşit ve büyüklüğü, alanı kullandıkları süre ve bu süre boyunca kullanıcıların katıldıkları rekreasyon aktiviteleri, alana geliş sıklıkları ve alanı hangi mevsimde kullandıklarını belirlemeye yönelik çoktan seçmeli sorular da hazırlanmıştır.

Alanda yapılan rekreasyonel faaliyetlere ziyaretçilerin katılım oranlarını belirlemek için 5 noktalı Likert ölçeği kullanılmıştır. Bu ölçeğe göre 1 "hiç" ve 5 "en çok" olarak değerlendirilmiştir.

Ziyaretçilerin rekreasyonel memnuniyetini ve bunu etkileyen kriterleri belirlemek için ise Parasurman ve ark., (1988)'nın müşteri memnuniyetini belirlemede kullandığı SERVQUAL yöntemi ile Mackay and Crompton, 1990'un rekreasyon alanlarındaki kullanıcı memnuniyetini belirlemede kullandığı REQUAL yönteminden yararlanılmıştır. $\mathrm{Bu}$ çalışmada ziyaretçilerin genel ve alandaki rekreasyonel memnuniyetlerini belirlemek amacı ile 21 ayrı kriter kullanılmıştır. Bu kriterlerin rekreasyonel memnuniyeti ölçmeye yönelik etki derecelerini belirlemek için 5 noktalı Likert ölçeğinden yararlanılmıştır. Bu ölçeğe göre 1 "etkisiz" ve 5 "çok etkili" olarak değerlendirilmiştir. Aynı şekilde rekreasyonel memnuniyetsizliği arttıran problemlerin etki derecelerini belirlemek için 6 noktalı Likert ölçeğinden yararlanılmıştır. Bu ölçeğe göre 1 "problem değil" ve 6 "çok fazla problem" olarak değerlendirilmiştir.

Son olarak ise ziyaretçilerin bu alandaki deneyim sonucunda elde ettikleri genel memnuniyet derecesini ölçmek için 5 seçenekli çoktan seçmeli bir soru daha yöneltilmiştir. 
Anketlerin değerlendirilmesi : Anketlerle elde edilen veriler SPSS 11.0 programı ile analiz edilmiştir. Genel rekreasyon alanlarındaki memnuniyet ve memnuniyetsizlik kriterleri ile Abant Tabiat Parkı'ndak memnuniyet ve memnuniyetsizlik kriterleri arasındaki ilişkilerin belirlenmesi için korelasyon analizi kullanılmıştır. Rekreasyon faaliyetlerine katılımın, Abant Tabiat Parkı'ndaki memnuniyet ve memnuniyetsizliklerin ROS sistemiyle oluşturulan alanlara göre farklılık gösterip göstermediğini belirlemek için varyans analizi One-Way ANOVA kullanılmıştır. Son olarak ise Abant Tabiat Parkı'ndaki kullanıcıların genel memnuniyetinin, ROS sistemine göre oluşturulmuş alanlar ile bu kullanıcıların soysa-demografik yapılarının farkılık gösterip göstermediğini ortaya koymak için varyans analizi tekrar kullanılmıştır.

\section{Bulgular}

Ankete katılanlar 359 kişi olup toplamda 897 saatlik görüşme yapılmıştır. Bazı ziyaretçiler çeşitli nedenlerle ankete katılmayı reddetmiştir. Görüşmenin \% 35'i "yolu olan doğal, primitif, kırsal, kentsel alanlarda”, \% 15’i "kırsal, kentsel, yolu olan doğal alanlarda", \% 18'i "yolu olan doğal primitif" alanlarda, \% 6'sı "yolu olan doğal" alanlarda, \% 8'i "yolu olan doğal, kentsel" alanlarda, \% 18'i "yolu olan doğal, primitif, yarı primitif, motorize" alanlarda yapılmıştır. Katılımcıların \% 47'si erkek, \% 53'ü kadındır. Ankete katılan ziyaretçilerin \% 17'sinin "0-18" yaş, \% 38 'inin "19-25" yaş, \%27'sinin "26-40" yaş, \%14'ünün "4160 ” yaş, \% 42'sinin 61 yaş üzeri olduğu belirlenmiştir.
Ankete katılan ziyaretçilerin \% 7'sinin "okur-yazar", \%17'sinin "ilköğretim mezunu", \% 36' sının "Lise Mezunu", \%37'sinin "Üniversite Mezunu", \% 3 'ünün "Yüksek lisans ve Üstü" eğitim düzeylerinde olduğu tespit edilmiştir. Katılımcıların \% 55'nin "0-800" YTL, \% 26' sının 801 1500 YTL, \%19'unun 1500YTL ve üzerinde aylık gelirinin olduğu belirlenmiştir. Katılımcıların Abant Tabiat Parkı'na geliş mesafeleri üç grupta değerlendirilmiştir: 0-100 km mesafeden gelen katılımcılar \% 41, $100-300 \mathrm{~km}$ mesafeden gelenler \% 46, $301 \mathrm{~km}$ üzeri mesafeden gelenler \% 13'lük kısmı oluşturmaktadır. Katılımcıların alana gelmeyi tercih ettikleri mevsimler değerlendirildiğinde ise, \% 44'ünün "İlkbahar", \% 21'inin "Yaz", \% 4'ünün "Sonbahar", \%5”'inin "Kış”, \%26'sının "Her mevsim" geldiği belirlenmiştir. Ankete katılanların \%55'i "Günübirlik kullanım", \%17'si "Bir gecelik kullanım”, \%28'i İki veya daha fazla gecelik kullanım için alanı tercih etmektedir. Ankete katılanların \%29'u "illk defa", \%14'ü "ayda bir" \%13ü "üç ayda bir", \%16'sı "altı ayda bir", \%21' "yılda bir", \%7'si "yılda birden az" alana gelmektedirler.

ROS sistemine göre alanların belirlenmesi : Abant Tabiat Parkı'nın ROS sistemi temel alınarak oluşturulan deneyim karakteristikleri, faaliyet tipleri, insan varlığı, konum karakteristikleri, sosyal konum, uzaklık ve yönetsel konum başlıkları haritaları altında primitif, yarı primitif motorize olmayan, yarı primitif motorize olan, yolu olan doğal, kırsal ve kentsel alanları içerip içermediğine ilişkin yapılan analiz sonuçlarına göre:

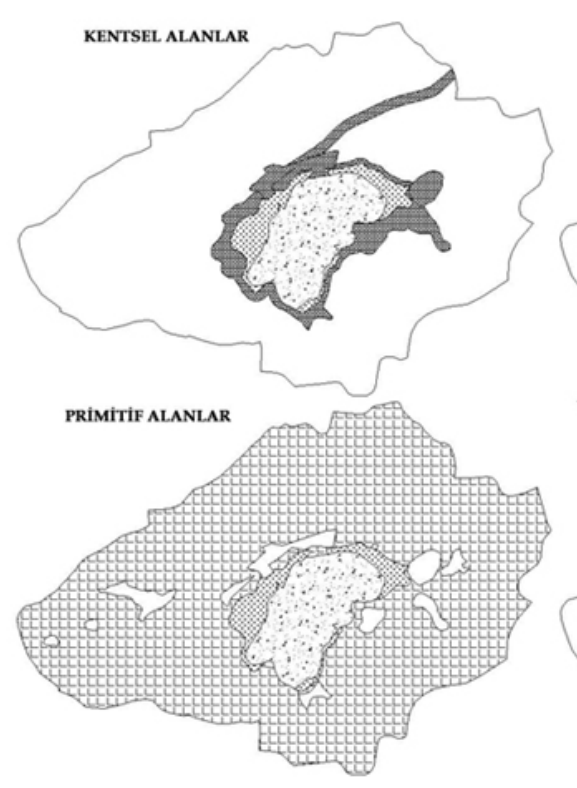

KENTSEL ALANLAR

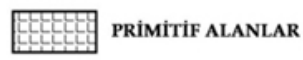

YOLU OLAN DOGAL ALANLAR

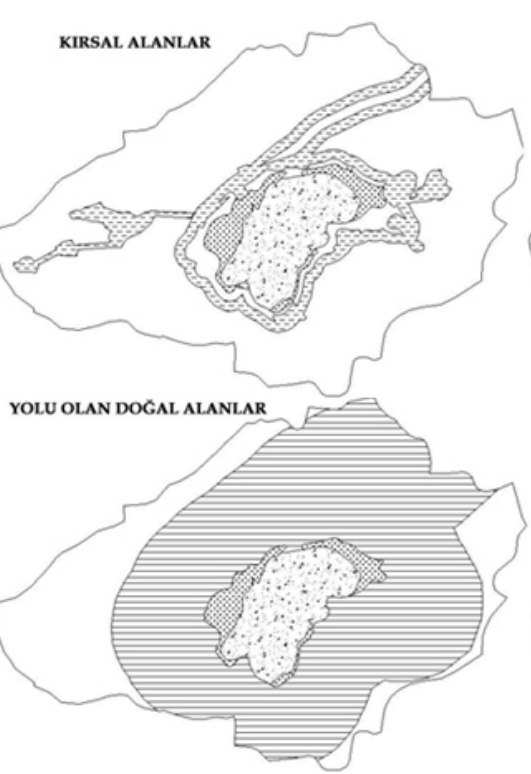

ABANT GOLOO

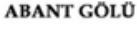

GOL KENARI BITKILERI

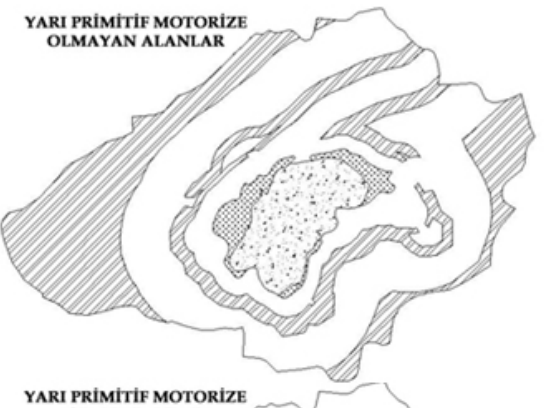

YARI PRIMITIF MOTORI
OLAN ALANLAR

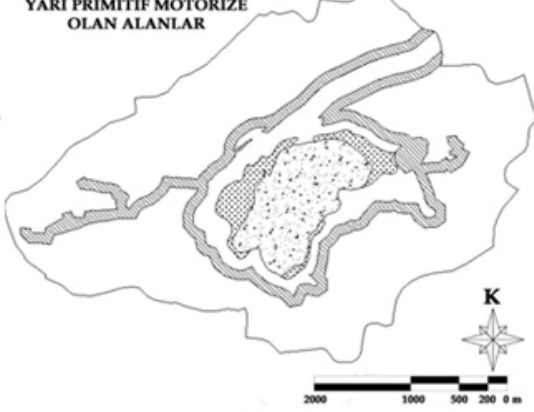

YARI PRIMITIF MOTORIZE OLMAYAN ALANLAR

YARI PRIMITIF MOTORIZ OLAN ALANLAR 
Abant Tabiat Parkı, deneyim karakteristiklerine göre primitif, yarı primitif motorize olmayan, yarı primitif motorize olan, yolu olan doğal, kırsal ve kentsel alanların tamamını içermektedir. Abant Tabiat Parkı, faaliyet tipleri kriterlerine göre, sadece primitif ve kırsal alanları içermektedir. Abant Tabiat Parkı, insan varlığı kriterlerine göre, primitif, yarı primitif motorize olmayan, yolu olan doğal, kırsal ve kentsel alanları içermektedir. Abant Tabiat Parkı, konum karakteristiklerine göre, primitif, yarı primitif motorize olmayan, yolu olan doğal, kırsal ve kentse alanları içermektedir. Abant Tabiat Parkı, sosyal konum kriterlerine göre primitif, yarı primitif motorize olmayan, kırsal ve kentsel alanları içermektedir. Abant Tabiat Parkı, uzaklık kriterlerine göre sadece yarı primitif motorize olmayan ve yolu olan doğal alanları içermektedir. Abant Tabiat Parkı, yönetsel konum kriterlerine göre ise primitif, yarı primitif motorize olmayan, yarı primitif motorize olan, yolu olan doğal, kırsal ve kentsel alanların tamamını içermektedir.

$\mathrm{Bu}$ aşamanın ardından anketlerin uygulandıkları bölgeler yolu olan doğal, primitif, kırsal ve kentsel özellikleri bir arada içeren alanlar (1 numara), kırsal, kentsel ve yolu olan doğal özellikleri bir arada içeren alanlar (2 numara), yolu olan doğal ve primitif özellikleri bir arada içeren alanlar (3 numara), yolu olan doğal alanlar (4 numara), yolu olan doğal ve kentsel özellikleri bir arada içeren alanlar (5 numara) ve yolu olan doğal, primitif ve yarı primitif motorize özellikleri bir arada içeren alanlar (6 numara) olarak tespit edilmiştir.

Genel ve alandaki memnuniyet kriterleri : Rekreasyon alanlarındaki genel memnuniyet kriterleri ile Abant Tabiat Parkı'ndaki memnuniyet kriterlerinin korelasyon analizi yapılmıştır. Bu analiz sonucunda genel ve alandaki memnuniyeti etkileyen kriterlerin tamamında istatistiksel olarak anlamlı benzerlikler gözlenmiştir. Bu kriterlerin etkileme derecelerinin bazı kriterler için yüksek, bazıları içinse düşük olduğu saptamıştır. Az para ile çok eğlenmek kriterinin genel rekreasyon alanlarındaki memnuniyete etkisi ile alandaki memnuniyete etkisi arasında yüksek oranda benzerlik olduğu saptanmıştır. Yeni insanlarla tanışmak kriterinin genel rekreasyon alanlarındaki memnuniyete etkisi ile alandaki memnuniyete etkisi arasında yüksek oranda benzerlik olduğu saptanmıştır. Aynı şekilde çocukların iyi zaman geçirmesi kriterinin genel rekreasyon alanlarındak memnuniyete etkisi ile alandaki memnuniyete etkisi arasında yüksek oranda benzerlik olduğu saptanmıştır. Bundan farklı olarak kişinin bedensel yeterliliğini deneyebilmesi kriterinin genel rekreasyon alanlarındaki memnuniyete etkisi ile alandaki memnuniyete etkisi arasında düşük oranda benzerlik olduğu saptanmıştır. Doğal bir çevrede boş zaman değerlendirmek kriterinin genel rekreasyon alanlarındaki memnuniyete etkisi ile alandaki memnuniyete etkisi arasında düşük oranda benzerlik olduğu saptanmıştır. Temiz havada egzersiz olanağı sağlanması kriterinin genel rekreasyon alanlarındaki memnuniyete etkisi ile alandaki memnuniyete etkisi arasında düşük oranda benzerlik olduğu saptanmıştır (Çizelge 1).

Genel ve alandaki memnuniyetsizlik kriterleri : Rekreasyon alanlarındaki genel memnuniyetsizlik kriterleri ile Abant Tabiat Parkı'ndaki memnuniyetsizlik kriterlerinin korelasyon analizi yapılmıştır. Bu analiz sonucunda genel ve alandaki memnuniyeti etkileyen kriterlerin tamamında istatistiksel olarak anlamlı benzerlikler gözlenmiştir. Bu kriterlerin etkileme derecelerinin bazı kriterler için yüksek, bazıları içinse düşük olduğu saptamıştır. Çok büyük kullanıcı grupları kriterinin genel rekreasyon alanlarındaki memnuniyetsizliğe etkisi ile alandaki memnuniyetsizliğe etkisi arasında yüksek oranda benzerlik olduğu saptanmıştır. Otopark eksikliği ve yollara araçların park etmesi kriterinin genel rekreasyon alanlarındaki memnuniyetsizliğe etkisi ile alandaki memnuniyetsizliğe etkisi arasında yüksek oranda benzerlik olduğu saptanmıştır. Çok fazla araç ve araç trafiği kriterinin genel rekreasyon alanlarındaki memnuniyetsizliğe etkisi ile alandaki memnuniyetsizliğe etkisi arasında yüksek oranda benzerlik olduğu saptanmıştır. Bundan farklı olarak yollarda çok fazla insan olması kriterinin genel rekreasyon alanlarındaki memnuniyetsizliğe etkisi ile alandaki memnuniyetsizliğe etkisi arasında düşük oranda benzerlik olduğu saptanmıştır. Tuvalet, çeşme, çöp kutusu vs. eksikliği kriterinin genel rekreasyon alanlarındaki memnuniyetsizliğe etkisi ile alandaki memnuniyetsizliğe etkisi arasında düşük oranda benzerlik olduğu saptanmıştır. Can ve mal güvenliği eksikliği kriterinin genel rekreasyon alanlarındaki memnuniyetsizliğe etkisi ile alandaki memnuniyetsizliğe etkisi arasında düşük oranda benzerlik olduğu saptanmıştır (Çizelge 2).

ROS sınırlarına göre alandaki kullanım tipleri : Abant Tabiat Parkında en çok yapılan rekreasyon faaliyetlerinin birincisinin manzara seyretmek, ikincisinin piknik yapmak, üçüncüsünün de yemek yemek ile yürüyüş yapmak olduğu tespit edilmiştir. ROS sistemine göre ayrılan alanlardaki kullanım tipleri karşılaştırıldığında ise, istatistiksel olarak anlamlı farklılara 11 tane rekreasyon faaliyetinde rastlanılmıştır. Alanda yapılan aktivitelerden biri olan kamp yapmak en çok "yolu olan doğal, kentsel" alanlarda, en az ise "yolu olan doğal, primitif, kırsal”, alanlarda yapılmaktadır. Spor en çok "kırsal, kentsel, yolu olan doğal" alanlarda, en az ise "yolu olan doğal, primitif" alanlarda yapılmaktadır. Koşmak en çok "kırsal, kentsel, yolu olan doğal" alanlarda, en az ise "yolu olan doğal, primitif, kırsal, kentsel" alanlarda yapılmaktadır. Piknik en çok "yolu olan doğal, primitif, yarı primitif, motorize" alanlarda, en az ise "kırsal, kentsel, yolu olan doğal" alanlarda yapılmaktadır. Seminerlere en çok "kırsal, kentsel, yolu olan doğal" alanlarda katıldıkları belirlenmiştir. Manzara en çok "yolu olan doğal, primitif, kırsal, kentsel" ve "kırsal, kentsel, yolu olan doğal" alanlarda seyredilirken, en az "yolu olan doğal, primitif, yarı primitif, motorize" alanlarda seyredildiği tespit edilmiştir (Çizelge 3).

ROS sınırlarına göre alandaki memnuniyet kriterleri : ROS sistemine göre ayrılan alanlardaki memnuniyet kriterleri karşılaştırıldığında istatistiksel olarak anlamlı farklılara 1 kriterde rastlanılmıştır. Yeni insanlarla tanışmak olan bu memnuniyet kriterinin, en çok "kırsal, kentsel, yolu olan doğal" alanlarda, en az ise "yolu olan doğal, primitif, yarı primitif motorize" alanlarda etkili olduğu belirlenmiştir (Çizelge 4). 
Çizelge 1. Genel ve alandaki memnuniyet kriterleri

\begin{tabular}{|c|c|c|c|}
\hline $\begin{array}{c}\text { Genel ve alandaki } \\
\text { memnuniyet kriterleri }\end{array}$ & $\begin{array}{l}\text { A.O. } \\
\text { Genel }\end{array}$ & $\begin{array}{l}\text { A.O. } \\
\text { Alan }\end{array}$ & Korelâsyon \\
\hline $\begin{array}{l}\text { Doğal çevre ve } \\
\text { manzara güzelliği }\end{array}$ & 4.2 & 4.1 & $0.571^{\star * *}$ \\
\hline Sessizlik ve huzur & 3.9 & 3.8 & $0.617^{\star \star \star}$ \\
\hline Doğayla ilişki olanağı & 4.0 & 3.9 & $0.501^{\star * \star}$ \\
\hline $\begin{array}{l}\text { Temiz havada } \\
\text { egzersiz olanağı } \\
\text { sağlaması }\end{array}$ & 3.5 & 3.6 & $0.440^{* * *}$ \\
\hline $\begin{array}{l}\text { Artık ve çöplerin } \\
\text { olmaması }\end{array}$ & 3.6 & 3.5 & $0.443^{* * *}$ \\
\hline $\begin{array}{l}\text { Yeni insanlarla } \\
\text { tanışmak }\end{array}$ & 2.7 & 2.8 & $0.698^{* * *}$ \\
\hline $\begin{array}{l}\text { Şehir stresinden ve } \\
\text { günlük rutinlerden } \\
\text { kurtulmak }\end{array}$ & 3.9 & 3.7 & $0.458^{* * *}$ \\
\hline $\begin{array}{l}\text { Doğayla birlikte tek } \\
\text { başına olma duygusu }\end{array}$ & 3.5 & 3.5 & $0.486^{* * *}$ \\
\hline $\begin{array}{l}\text { Doğal bir çevrede boş } \\
\text { zaman } \\
\text { değerlendirmek }\end{array}$ & 3.6 & 3.5 & $0.426^{\star \star *}$ \\
\hline $\begin{array}{l}\text { Diğer insanlardan ayrı } \\
\text { ailem ve dostlarımla } \\
\text { baş başa olma fırsatı }\end{array}$ & 3.5 & 3.6 & $0.601^{* * *}$ \\
\hline $\begin{array}{l}\text { Büyük gruplarla } \\
\text { eğlenceli bir ortamda } \\
\text { bulunma fırsatı }\end{array}$ & 3.2 & 3.0 & $0.577^{\star \star *}$ \\
\hline $\begin{array}{l}\text { Kullanıcı sayısının } \\
\text { fazla olması }\end{array}$ & 2.8 & 2.9 & $0.581^{\text {*** }}$ \\
\hline $\begin{array}{l}\text { Kullanıcı sayısının az } \\
\text { olması }\end{array}$ & 2.9 & 2.9 & $0.592^{* * *}$ \\
\hline $\begin{array}{l}\text { Doğal alanlar } \\
\text { hakkında bilgi } \\
\text { edinmek }\end{array}$ & 3.3 & 3.2 & $0.625^{\star * *}$ \\
\hline $\begin{array}{l}\text { Değişik manzaralar } \\
\text { görmek }\end{array}$ & 3.9 & 3.8 & $0.449^{* * *}$ \\
\hline $\begin{array}{l}\text { Kişinin bedensel } \\
\text { yeterliliğini } \\
\text { deneyebilmesi }\end{array}$ & 3.2 & 3.1 & $0.416^{\star * *}$ \\
\hline $\begin{array}{l}\text { Macera ve keşif } \\
\text { duygusu }\end{array}$ & 3.3 & 3.2 & $0.501^{* * *}$ \\
\hline $\begin{array}{l}\text { Seyahat becerilerini } \\
\text { geliştirmek }\end{array}$ & 3.2 & 3.2 & $0.538^{* * *}$ \\
\hline $\begin{array}{l}\text { Çocuklarımın iyi } \\
\text { zaman geçirmesi }\end{array}$ & 3.1 & 3.1 & $0.674^{* * *}$ \\
\hline $\begin{array}{l}\text { Farklı deneyimleri } \\
\text { tatmak }\end{array}$ & 3.4 & 3.4 & $0.613^{* * *}$ \\
\hline $\begin{array}{l}\text { Az para ile çok } \\
\text { eğlenmek }\end{array}$ & 3.4 & 3.2 & $0.738^{\star \star *}$ \\
\hline
\end{tabular}

"1" Etkisiz, "2" Az Etkili,"3" Etkili , "4" Oldukça Etkili, "5" Çok Etkili ${ }^{*} p<0,05 ;{ }^{* *} p<0,005 ;{ }^{* * *} p<0,001$ A.O.: Aritmetik ortalama

ROS sınıflarına göre alandaki memnuniyetsizlik kriterleri : ROS sistemine göre ayrılan alanlardaki memnuniyetsizlik kriterleri karşılaştırıldığında istatistiksel olarak anlamlı farkılıra 8 kriterde rastlanılmıştır. Bu memnuniyetsizlik kriterlerinden biri olan gürültü ve yüksek sesli insanların, en çok "yolu olan doğal" alanlarda, nispeten daha düşük olmak üzere "kırsal, kentsel, yolu olan doğal" alanlarda problem yarattığı belirlenmiştir. Tasmasız ve kontrolsüz hayvanların en çok "yolu olan doğal, kentsel" alanlarda, nispeten daha düşük olmak üzere "kırsal, kentsel, yolu olan doğal" alanlarda problem yarattığı belirlenmiştir. Çok fazla telefon ve diğer elektronik gereçleri kullanan kullanıcıların en çok "yolu olan doğal, primitif" alanlarda, nispeten daha düşük olmak üzere "yolu olan doğal" alanlarda rahatsızlık verdiği tespit edilmiştir.
Çizelge 2. Genel ve alandaki memnuniyetsizlik kriterleri

\begin{tabular}{|c|c|c|c|}
\hline $\begin{array}{l}\text { Genel ve alandaki } \\
\text { memnuniyetsizlik } \\
\text { kriterleri }\end{array}$ & $\begin{array}{l}\text { A.O. } \\
\text { Genel }\end{array}$ & $\begin{array}{l}\text { A.O. } \\
\text { Alan }\end{array}$ & Korelâsyon \\
\hline $\begin{array}{l}\text { Yollarda çok fazla } \\
\text { insan olması }\end{array}$ & 3.6 & 3.9 & $0.22^{* \star *}$ \\
\hline $\begin{array}{l}\text { Yönlendirme ve uyarı } \\
\text { levhaları eksikliği }\end{array}$ & 3.8 & 3.6 & $0.53^{* \star *}$ \\
\hline $\begin{array}{l}\text { Kamplarda ve piknik } \\
\text { alanlarında çok fazla } \\
\text { insan }\end{array}$ & 3.7 & 3.6 & $0.55^{\star \star \star}$ \\
\hline $\begin{array}{l}\text { Çok büyük kullanıcı } \\
\text { gruplar }\end{array}$ & 3.7 & 3.6 & $0.70^{* \star *}$ \\
\hline $\begin{array}{l}\text { Yollar piknik ve kamp } \\
\text { alanlarındaki çöpler }\end{array}$ & 4.6 & 4.2 & $0.51^{* * *}$ \\
\hline $\begin{array}{l}\text { Kamp ve piknik } \\
\text { yerleri hakkında } \\
\text { yeterince bilgi } \\
\text { olmaması }\end{array}$ & 4.0 & 3.7 & $0.52^{* \star *}$ \\
\hline $\begin{array}{l}\text { Gürültü ve yüksek } \\
\text { sesli insanlar }\end{array}$ & 4.2 & 3.9 & $0.50^{* \star \star}$ \\
\hline $\begin{array}{l}\text { İnsanların çöp } \\
\text { artıklarının çok } \\
\text { olması }\end{array}$ & 4.8 & 4.4 & $0.44^{\star \star \star}$ \\
\hline $\begin{array}{l}\text { Tasmasız ve } \\
\text { kontrolsüz köpekler }\end{array}$ & 4.2 & 3.9 & $0.51^{* * *}$ \\
\hline $\begin{array}{l}\text { Çok fazla kısıtlama } \\
\text { ve kontroller }\end{array}$ & 3.5 & 3.3 & $0.60^{* * *}$ \\
\hline $\begin{array}{l}\text { Çok fazla telefon ve } \\
\text { diğer elektronik } \\
\text { gereçleri kullanan } \\
\text { diğer kullanıcılar }\end{array}$ & 3.1 & 3.0 & $0.50^{* \star \star}$ \\
\hline $\begin{array}{l}\text { Çok az görevlilerinin } \\
\text { bulunması }\end{array}$ & 3.5 & 3.3 & $0.41^{* * *}$ \\
\hline $\begin{array}{l}\text { Çok sayıda fiziksel } \\
\text { yapı görmek (Bina- } \\
\text { vs.) }\end{array}$ & 3.7 & 3.3 & $0.51^{* \star \star}$ \\
\hline Yolların bakımsızlığı & 4.4 & 4.0 & $0.50^{* \star \star}$ \\
\hline Tuvalet kirliliği & 4.9 & 4.4 & $0.40^{* * *}$ \\
\hline $\begin{array}{l}\text { Tuvalet, çeşme,çöp } \\
\text { kutusu, vs. eksikliği }\end{array}$ & 5.0 & 4.7 & $0.23^{* \star *}$ \\
\hline $\begin{array}{l}\text { Çok fazla kömür kül } \\
\text { ve mangal ateşi } \\
\text { görmek }\end{array}$ & 4.1 & 3.7 & $0.50^{* * *}$ \\
\hline $\begin{array}{l}\text { Su kirliliği ve doğal } \\
\text { alanlarda bakım } \\
\text { onarım çalışmalarının } \\
\text { yapıımaması }\end{array}$ & 4.3 & 3.9 & $0.34^{* * *}$ \\
\hline $\begin{array}{l}\text { Can ve mal güvenliği } \\
\text { eksikliği }\end{array}$ & 4.2 & 3.7 & $0.30^{* \star \star}$ \\
\hline $\begin{array}{l}\text { Otopark eksikliği ve } \\
\text { yollara araçların park } \\
\text { etmesi }\end{array}$ & 4.4 & 4.2 & $0.62^{\star \star \star}$ \\
\hline $\begin{array}{l}\text { Çok fazla araç ve } \\
\text { araç trafiği }\end{array}$ & 4.4 & 4.3 & $0.60^{* * *}$ \\
\hline
\end{tabular}

"1" Problem Değil, "2" Az Problem, "3" Kısmen Problem, "4" Problem, "5" Çok Problem, "6" Çok Fazla Problem

${ }^{*} p<0,05 ;{ }^{* *} p<0,005 ;{ }^{* * *} p<0,001$ A.O.: Aritmetik Ortalama

Yolların bakımsızlığı en çok "yolu olan doğal" alanlarda, nispeten daha düşük olmak üzere "kırsal, kentsel, yolu olan doğal" alanlarda problem yaratmaktadır. Tuvalet kirliliği en çok "yolu olan doğal, primitif, yarı primitif motorize" alanlarda, nispeten daha düşük olmak üzere "kırsal, kentsel, yolu olan doğal" alanlarda problem yarattığı belirlenmiştir. Tuvalet, çeşme, çöp kutusu, vs. eksikliği en çok "yolu olan doğal" alanlarda, nispeten daha düşük olmak üzere "kırsal, kentsel, yolu olan doğal" alanlarda rahatsızlık verdiği belirlenmiştir. Çok fazla kömür 
kül ve mangal ateşi görmenin en çok "yolu olan doğal, primitif, yarı primitif, motorize" alanlarda nispeten daha düşük olmak üzere "kırsal, kentsel, yolu olan doğal" alanlarda rahatsızlık verildiği belirlenmiştir. Can ve mal güvenliğinin eksikliği en çok "yolu olan doğal, primitif, yarı primitif, motorize" alanlarda, nispeten daha düşük olmak üzere "kırsal, kentsel, yolu olan doğal" alanlarda hissedildiği belirlenmiştir (Çizelge 5).

Çizelge 3. ROS sınırlarına göre alandaki kullanım tipleri

\begin{tabular}{|c|c|c|c|c|c|c|c|c|}
\hline $\begin{array}{l}\text { ROS Sınırlarına Göre } \\
\text { Alandaki Kullanım Tipleri }\end{array}$ & 1 & 2 & 3 & 4 & 5 & 6 & $\begin{array}{l}\text { Aritmetik } \\
\text { ortalama }\end{array}$ & $\begin{array}{l}\text { Varyans } \\
\qquad(F)\end{array}$ \\
\hline Manzara seyretmek & 4.40 & 4.40 & 4.11 & 4.05 & 4.20 & 3.80 & 4.2 & $3.60^{* *}$ \\
\hline Yürüyüş yapmak & 3.80 & 3.60 & 3.90 & 3.74 & 3.60 & 3.44 & 3.7 & 1.40 \\
\hline Koşmak & 2.23 & 2.81 & 2.70 & 2.65 & 2.30 & 2.24 & 2.4 & $2.38^{*}$ \\
\hline Spor yapmak & 2.24 & 2.98 & 2.53 & 2.40 & 2.53 & 2.50 & 2.5 & $2.29^{*}$ \\
\hline Bisiklete binmek & 1.80 & 2.30 & 2.02 & 2.21 & 1.73 & 1.80 & 2.00 & 1.48 \\
\hline Ata binmek & 1.83 & 2.04 & 1.80 & 2.25 & 1.65 & 1.60 & 1.8 & 1.60 \\
\hline Kızakla kaymak & 2.00 & 2.11 & 1.60 & 2.30 & 2.13 & 1.55 & 1.9 & $2.32^{*}$ \\
\hline Piknik yapmak & 4.03 & 3.12 & 3.52 & 4.10 & 4.00 & 4.21 & 3.8 & $6.30^{\star * *}$ \\
\hline Fotoğraf çekmek & 3.50 & 3.80 & 3.05 & 3.11 & 3.52 & 3.50 & 3.4 & 1.80 \\
\hline Balık tutmak & 1.81 & 2.16 & 2.18 & 2.00 & 1.7 & 1.82 & 1.9 & 1.23 \\
\hline Çeşitli oyunlar oynamak & 2.85 & 2.35 & 2.90 & 2.90 & 3.45 & 2.85 & 2.8 & $2.21^{*}$ \\
\hline Kamp yapmak & 1.83 & 2.32 & 2.05 & 1.00 & 4.13 & 1.90 & 2.1 & $20.71^{\star \star \star}$ \\
\hline Doğayla ilişki kurmak & 3.44 & 3.32 & 3.06 & 3.00 & 3.63 & 3.21 & 3.3 & 1.37 \\
\hline Kendi başına kalmak & 2.80 & 2.80 & 2.40 & 3.40 & 3.74 & 2.62 & 2.8 & $1.27^{*}$ \\
\hline $\begin{array}{l}\text { Keşif amacıyla dolaşmak ve } \\
\text { uzaklaşmak }\end{array}$ & 2.70 & 3.10 & 2.50 & 2.25 & 3.14 & 2.50 & 2.7 & 1.27 \\
\hline Diğer ziyaretçiler ile tanışmak & 2.00 & 2.92 & 2.20 & 2.60 & 2.24 & 2.05 & 2.2 & $4.46^{\star \star \star}$ \\
\hline Kitap okumak & 2.35 & 2.80 & 2.70 & 3.90 & 2.50 & 2.15 & 2.5 & 6.03 \\
\hline Yemek yemek & 3.85 & 3.60 & 3.35 & 3.53 & 3.72 & 3.90 & 3.7 & 2.00 \\
\hline Dinlenmek & 3.50 & 3.80 & 3.25 & 3.53 & 3.75 & 3.70 & 3.5 & 1.44 \\
\hline Otelde konaklamak & 1.70 & 3.00 & 2.00 & 1.00 & 1.90 & 1.60 & 1.9 & 11.69 \\
\hline Gruplar halinde eğlenmek & 3.40 & 3.02 & 3.03 & 1.00 & 3.03 & 3.30 & 3.1 & $10.27^{* * *}$ \\
\hline Seminerlere katılmak & 1.70 & 2.20 & 1.90 & 1.00 & 1.60 & 1.40 & 1.7 & $4.35^{\star \star \star}$ \\
\hline
\end{tabular}

Aktivite sıklığı: 1 "hiç”, 2 “az", 3 “orta”, 4 "sık”, 5 “çok sık” * $p<0,05 ;{ }^{* *} p<0,005$; *** $p<0,001$

1: Yolu olan doğal, primitif, kırsal, kentsel 2: Kırsal, kentsel, yolu olan doğal 3: Yolu olan doğal, primitif 4: Yolu olan doğal

5: Yolu olan doğal, kentsel 6: Yolu olan doğal, primitif, yarı primitif motorize

Çizelge 4. ROS sınırlarına göre alandaki memnuniyet kriterleri

\begin{tabular}{|c|c|c|c|c|c|c|c|}
\hline $\begin{array}{l}\text { ROS Sınırlarına Göre Alandaki } \\
\text { Memnuniyet Kriterleri }\end{array}$ & 1 & 2 & 3 & 4 & 5 & 6 & $\begin{array}{l}\text { Varyans } \\
(\mathrm{F})\end{array}$ \\
\hline Doğal çevre ve manzara güzelliği & 4.30 & 4.15 & 3.91 & 4.14 & 4.10 & 4.00 & 1.14 \\
\hline Sessizlik ve huzur & 4.00 & 4.02 & 3.60 & 3.80 & 3.70 & 3.65 & 1.60 \\
\hline Doğayla ilișki olanağı & 4.00 & 4.00 & 3.71 & 3.90 & 4.00 & 3.95 & 0.53 \\
\hline Temiz havada egzersiz olanağı sağlaması & 3.60 & 3.70 & 3.55 & 3.75 & 3.85 & 3.60 & 0.30 \\
\hline Artık ve çöplerin olmaması & 3.41 & 3.70 & 3.62 & 3.31 & 3.43 & 3.50 & 0.50 \\
\hline Yeni insanlarla tanışmak & 2.70 & 3.44 & 2.74 & 2.90 & 2.75 & 2.40 & $3.24^{*}$ \\
\hline Sehir stresinden ve günlük rutinlerden kurtulmak & 3.74 & 4.00 & 3.51 & 3.65 & 3.75 & 3.55 & 0.90 \\
\hline Doğayla birlikte tek başına olma duygusu & 3.51 & 3.63 & 3.60 & 3.33 & 3.25 & 3.40 & 0.60 \\
\hline Doğal bir cevrede bos zaman değerlendirmek & 3.52 & 3.74 & 3.40 & 3.70 & 3.70 & 3.40 & 0.70 \\
\hline $\begin{array}{l}\text { Diğer insanlardan ayrı ailem ve dostlarımla baş başa } \\
\text { olma fırsatı }\end{array}$ & 3.82 & 3.65 & 3.40 & 3.33 & 3.35 & 3.40 & 1.80 \\
\hline Büyük gruplarla eğlenceli bir ortamda bulunma fırsatı & 3.21 & 2.71 & 3.10 & 2.80 & 2.75 & 2.80 & 1.50 \\
\hline Kullanıcı sayısının fazla olması & 3.00 & 3.00 & 2.80 & 2.70 & 2.70 & 2.70 & 0.70 \\
\hline Kullanıcı sayısının az olması & 3.00 & 3.00 & 2.60 & 2.55 & 2.65 & 3.00 & 1.30 \\
\hline Doğal alanlar hakkında bilgi edinmek & 3.30 & 3.40 & 3.03 & 3.00 & 3.00 & 3.30 & 0.90 \\
\hline Değişik manzaralar görmek & 3.90 & 3.80 & 3.60 & 3.70 & 3.83 & 3.80 & 0.51 \\
\hline Kişinin bedensel yeterliliğini deneyebilmesi & 2.93 & 3.30 & 3.20 & 3.10 & 3.24 & 3.20 & 0.65 \\
\hline Macera ve keşif duygusu & 3.10 & 3.04 & 3.20 & 3.00 & 3.40 & 3.40 & 0.71 \\
\hline Seyahat becerilerini geliştirmek & 3.30 & 3.20 & 3.10 & 2.90 & 3.13 & 3.20 & 0.60 \\
\hline Çocuklarımın iyi zaman geçirmesi & 3.23 & 3.04 & 2.90 & 2.65 & 3.62 & 3.42 & 1.80 \\
\hline Farklı deneyimleri tatmak & 3.70 & 3.23 & 3.20 & 3.05 & 3.55 & 3.50 & 2.02 \\
\hline Az para ile cok eğlenmek & 3.40 & 3.00 & 3.35 & 3.14 & 2.93 & 3.30 & 1.03 \\
\hline
\end{tabular}

Etki dereceleri: 1 "etkisiz", 2 "az etkili", 3 "etkili", 4 "oldukça etkili", ve 5 "çok etkili". " $p<0,05 ;{ }^{* *} p<0,005 ;{ }^{* * *}<<0,001$

1: Yolu olan doğal, primitif, kırsal, kentsel 2: Kırsal, kentsel, yolu olan doğal 3: Yolu olan doğal, primitif 4: Yolu olan doğal

5: Yolu olan doğal, kentsel 6: Yolu olan doğal, primitif, yarı primitif motorize 
Parkı'nda kullanıcı memnuniyetinin belirlenmesi"

Çizelge 5. ROS sınıflarına göre alandaki memnuniyetsizlik kriterleri

\begin{tabular}{|c|c|c|c|c|c|c|c|}
\hline ROS Sınıflarına Göre Alandaki Memnuniyetsizlik Kriterleri & 1 & 2 & 3 & 4 & 5 & 6 & $\begin{array}{c}\text { Varyans } \\
(\mathrm{F})\end{array}$ \\
\hline Yollarda çok fazla insan olması & 3.80 & 3.65 & 3.90 & 5.53 & 5.00 & 3.32 & 1.34 \\
\hline Yönlendirme ve uyarı levhaları eksikliği & 3.80 & 2.92 & 3.70 & 3.42 & 3.70 & 3.80 & 3.00 \\
\hline Kamplarda ve piknik alanlarında çok fazla insan & 3.70 & 3.08 & 3.90 & 3.63 & 3.50 & 3.65 & 1.50 \\
\hline Çok büyük kullanıcı gruplar & 3.80 & 3.20 & 3.83 & 3.74 & 3.44 & 3.60 & 1.24 \\
\hline Yollar piknik ve kamp alanlarındaki çöpler & 4.21 & 3.70 & 4.22 & 4.35 & 4.11 & 4.42 & 1.60 \\
\hline Kamp ve piknik yerleri hakkında yeterince bilgi olmaması & 3.80 & 3.14 & 4.00 & 3.31 & 3.50 & 4.00 & 2.80 \\
\hline Gürültü ve yüksek sesli insanlar & 4.00 & 3.42 & 4.10 & 4.33 & 4.15 & 4.00 & $1.40^{*}$ \\
\hline İnsanların çöp artıklarının çok olması & 4.43 & 3.65 & 4.60 & 4.65 & 4.25 & 4.60 & 2.90 \\
\hline Tasmasız ve kontrolsüz hayvanlar & 3.90 & 3.33 & 4.00 & 4.05 & 4.15 & 4.10 & $1.60^{*}$ \\
\hline Çok fazla kısıtlama ve kontroller & 3.33 & 2.90 & 3.60 & 3.40 & 3.44 & 3.43 & 1.12 \\
\hline Çok fazla telefon ve diğer elektronik gereçleri kullanan diğer kullanıcılar & 3.10 & 2.70 & 3.50 & 2.10 & 2.73 & 3.24 & $2.85^{\star}$ \\
\hline Çok az görevlilerinin bulunması & 3.30 & 3.00 & 3.52 & 3.05 & 3.30 & 3.25 & 0.85 \\
\hline Çok sayıda fiziksel yapı görmek (Bina-vs.) & 3.40 & 2.74 & 3.50 & 2.90 & 2.85 & 3.61 & 2.20 \\
\hline Yolların bakımsızlığı & 3.92 & 3.70 & 4.24 & 4.70 & 4.53 & 3.83 & $2.24^{*}$ \\
\hline Tuvalet kirliliği & 4.62 & 3.70 & 4.60 & 4.20 & 4.32 & 4.80 & $3.25^{\star *}$ \\
\hline Tuvalet, çeşme ,çöp kutusu, vs. eksikliği & 4.90 & 3.90 & 4.71 & 5.00 & 4.90 & 4.74 & $3.75^{\star *}$ \\
\hline Çok fazla kömür kül ve mangal ateşi görmek & 3.72 & 3.20 & 4.24 & 3.35 & 3.50 & 3.85 & $3.10^{*}$ \\
\hline Su kirliliği ve doğal alanlarda bakım onarım çalışmalarının yapıımaması & 3.80 & 3.40 & 4.20 & 4.05 & 4.00 & 4.00 & 2.80 \\
\hline Can ve mal güvenliği eksikliği & 3.52 & 2.90 & 4.10 & 3.40 & 3.81 & 4.14 & $4.10^{* * *}$ \\
\hline Otopark eksikliği ve yollara araçların park etmesi & 4.18 & 3.83 & 4.22 & 4.50 & 4.50 & 4.40 & 1.11 \\
\hline Çok fazla araç ve araç trafiği & 4.25 & 4.10 & 4.33 & 4.70 & 4.50 & 4.25 & 0.53 \\
\hline
\end{tabular}

Problem dereceleri: 1 "problem değil", 2 "az problem", 3 "kısmen problem", 4 "problem", 5 "çok problem" ve 6 "çok fazla problem".

${ }^{*} p<0,05 ;{ }^{* *} p<0,005 ;{ }^{* * *} p<0,001$

1: Yolu olan doğal, primitif, kırsal, kentsel 2: Kırsal, kentsel, yolu olan doğal 3: Yolu olan doğal, primitif 4: Yolu olan doğal

5: Yolu olan doğal, kentsel 6: Yolu olan doğal, primitif, yarı primitif motorize

Genel memnuniyeti etkileyen alan ve kullanıcı özellikleri : Abant Tabiat Parkındaki rekreasyonel faaliyetlere katılan kullanıcıların alanda edindikleri genel memnuniyetleri ile ziyaretçi özelliklerine göre farklılık gösterip göstermediğini belirlemek için varyans analizi One-Way ANOVA kullanılmıştır. $\mathrm{Bu}$ özellikler karşılaştırıldığında istatistiksel olarak 6 tane anlamlı farklık belirlenmiştir. Genel olarak kullanıcıların alandaki rekreasyonel deneyimleri sonucunda "oldukça memnun" oldukları belirlenmiştir. Kadınların, erkeklere göre alandan daha fazla memnun oldukları, yaş kriterine göre de, 0- 25 yaş arası kullanıcılar en fazla memnuniyet duyarken 61 yaş üstü kullanıcıların nispeten daha az memnuniyet duydukları belirlenmiştir. Kullanıcıların gelir düzeyine göre, alandan edindikleri memnuniyetlerinin değişim gösterdiği saptanmıştır. En memnun kullanıcıların aylık geliri 0 - 800 YTL arasında iken, 801 - 1500 YTL arası aylık geliri olanların nispeten daha az memnuniyet duydukları belirlenmiştir. Alana farklı ulaşım mesafelerinden gelen kullanıcıların genel olarak alandan "oldukça memnun" oldukları belirlenmiştir. Alana ulaşım mesafesi 100 - $300 \mathrm{~km}$ olan kullanıcılar en fazla memnuniyet duyarken, $0-100 \mathrm{~km}$ ulaşım mesafesinden gelenlerin ise nispeten daha az memnun oldukları belirlenmiştir. Kullanıcıların alandan mevsimlere göre en fazla sonbahar aylarında memnun oldukları belirlenmiştir (Çizelge 6).
Çizelge 6. Genel memnuniyeti etkileyen alan ve kullanıcı özellikleri

\begin{tabular}{|c|c|c|c|}
\hline & & $\mathrm{AO}$ & Varyans (F) \\
\hline \multirow[b]{2}{*}{ Cinsiyet } & Erkek & 3.25 & \multirow{2}{*}{$2.84^{*}$} \\
\hline & Kadın & 3.50 & \\
\hline \multirow{5}{*}{ Yaş } & $0-18$ & 3.50 & \multirow{5}{*}{$4.63^{* * *}$} \\
\hline & $19-25$ & 3.50 & \\
\hline & $26-40$ & 3.35 & \\
\hline & $41-60$ & 3.20 & \\
\hline & $61+$ & 2.80 & \\
\hline \multirow{3}{*}{ Gelir } & $0-800$ YTL & 3.40 & \multirow{3}{*}{$2.90^{*}$} \\
\hline & $801-1500$ YTL & 3.25 & \\
\hline & 1,5 milyar üzeri & 3.30 & \\
\hline \multirow{3}{*}{$\begin{array}{l}\text { Geldiğiniz } \\
\text { Yer }\end{array}$} & $0-100 \mathrm{~km}$ & 3.30 & \multirow{3}{*}{$3.26^{*}$} \\
\hline & $100-300 \mathrm{~km}$ & 3.50 & \\
\hline & $301+$ & 3.33 & \\
\hline \multirow{5}{*}{ Mevsim } & İlkbahar & 3.50 & \multirow{5}{*}{$4.80^{* * *}$} \\
\hline & Yaz & 3.53 & \\
\hline & Sonbahar & 4.00 & \\
\hline & Kış & 3.00 & \\
\hline & Her mevsim & 3.10 & \\
\hline \multirow{4}{*}{$\begin{array}{l}\text { Grup } \\
\text { büyüklüğü }\end{array}$} & Yalnız & 3.40 & \multirow{4}{*}{$2.90^{*}$} \\
\hline & Arkadaşlar ile & 3.60 & \\
\hline & Ailem ile & 3.20 & \\
\hline & Organizasyon ile & 3.12 & \\
\hline
\end{tabular}

Genel memnuniyet dereceleri: 1 "hiç memnun değilim", 2 "az memnunum", 3 "memnunum", 4 "oldukça memnunum", 5 "çok memnunum" $\quad{ }^{*} p<0,05 ;{ }^{* *} p<0,005 ;{ }^{* * *} p<0,001$

A.O.: Aritmetik ortalama 


\section{Sonuç}

Bu çalışmada ROS sınıflarına göre alanları kullanan ziyaretçilerin memnuniyetlerindeki memnuniyetsizliklerindeki farklulkları ve benzerliklei belirlemek amacıyla Abant Tabiat Parkı'ndaki ziyaretçilerin profilleri incelenmiş ve rekreasyonel kullanımlara katılımları saptanmıştır.

ROS sistemi uygulanırken, ortaya konan sınıfların birbirlerinden net çizgilerle ayrıımadığı, zayıf tanımlanmış bazı standartlar sebebiyle kavramların çakıştığı ve bu yüzden sorunların ortaya çıktığı belirlenmiştir. Örneğin çalışmalar sırasında, bir alan farklı haritalarda farklı özelliklerinden dolayı hem kentsel hem de kırsal sınıfa dahil olabilmektedir. More ve ark., (2003) yaptıkları bir çalışmada benzer sonuçlarla karşılaşmışlar ve bunu şöyleaçıklamışlardır: "Çeşitli kategoriler karşılaştırılınca bilmeceye benzer bir durumla karşılaştık: Bir kentte kırsal bir alan olabilir mi? Sonuçta farkına vardık ki biz hem gelişimin devamlılığı hem de doğallığın arttırılması ile meşgul oluyoruz". Bunun sorunların çözümü için Türkiye standartlarına göre ROS sistemi sınıflarının tekrar belirlenmesi, daha net standartlara oturtulması, ROS dilinin açıklanması ve kolay anlaşılırlığının sağlanması gerekmektedir. Çizelge 1'de görüldüğü üzere bu alanları kullanan kişilerin genel memnuniyetten beklentileri ile alandan edindikleri memnuniyetlerinin benzer olduğu gözlenmiştir. Fakat bazı kriterlerden oluşan memnuniyetlerde farklılıklara rastlanılmıştır. Bu farklılıklar kişilerin alana geliş amaçları ve alanın kullanıcılara sunduğu olanaklara bağlı olarak değişiklik göstermektedir. Alanın sunduğu olanaklara bağlı olarak kişilerin alanı kullanma şekilleri (amaçları) da değişebilmektedir. Alanın taşıma kapasitesinin doğru bir şekilde belirlenmesi, sunduğu doğal özelliklerinin, kullanım tipi ve şeklinin, aktivite çeşitlerinin ziyaretçilere tanıtımının yapılması bilinçli bir kullanıcı kitlesinin yaratılmasını sağlayacak ve bu kişilerin alandan elde edecekleri memnuniyetin yükselmesine yardımcı olacaktır. Çizelge 2'de görüldüğü üzere kullanıcılar beklentilerinin altında bir memnuniyetsizlikle karşılaştıkları durumda bunu tolere edebilmelerine rağmen, beklentilerinin üzerinde bir memnuniyetsizlikle karşılaştıkları durumda bunu tolere edememektedirler. Örneğin anket sonuçlarına göre kullanıcılar, "yollarda çok fazla insan olması" kriterini genel rekreasyon alanlarında bir memnuniyetsizlik kriteri olarak tanımlarken, Abant Tabiat Parkı'nda elde ettikleri bu deneyimin beklentilerinin üzerinde bir memnuniyetsizlik kriteri olarak ortaya çıktığını ifade etmişlerdir.

Çizelge 3'te görüldüğü üzere ROS sistemiyle ayrılmış alanlardaki kullanımlar ile ROS faaliyet tipleri karşılaştırıldığında, kullanımlar arasında farklılık gözlenmemiş, aynı veya benzer kullanımların varlığı saptanmıştır.

Çizelge 4’te görüldüğü üzere “yeni insanlarla tanışmak" kriteri hariç verilen memnuniyet kriterlerinin ROS sistemindeki kategorilere göre değişim göstermeği gözlenmektedir. Bu çalışmada, kullanılan memnuniyet kriterlerinin, Abant Tabiat Parkı'ndaki memnuniyet kriterlerini tam olarak ortaya koyamadığı gözlenmiştir. Bu kriterler daha çok bütün alanlarda olması gereken genel memnuniyet kriterleridir. Bu nedenle de yeni çalışmalarda ROS sistemi düşünülerek ayrılan alanlara göre memnuniyet kriterleri oluşturulmalı ve bu alanlar için memnuniyetin arttırılmasına yönelik çalışmalar yapılmalıdır.

Çizelge 5 'te görüldüğü üzere, buradaki memnuniyetsizlik kriterlerinin Çizelge 4'teki memnuniyet kriterlerine göre ROS sistemiyle ayrılmış alanlar bazında daha uygun bir şekilde belirlendiği ve bunun sonucu olarak daha fazla anlamlı farklıı̆ga ulaşıldığı gözlenmektedir. Burns ve ark. (1998) yaptıkları çalışmada ziyaretçilerin yaşlarındaki değişimin alanın kalitesini belirleyen altyapı ve hizmet beklentilerinde de etkili olduğunu belirtmektedirler. Abant Tabiat Parkı'nda da dile getirilen problemlerin, daha çok alanın yönetiminden ve altyapı eksikliğinden kaynaklandığı belirlenmiştir. Bu problemlerin ROS kriterlerine göre ayrılmış alanlarda farklılık gösterdiği tespit edilmiştir. Özellikle altyapı eksikliği alandaki kullanıcı memnuniyetinin olumsuz yönde etkilenmesine sebep olduğu için altyapıya dair iyileştirme çalışmalarının başlatılması gerekmektedir. Özellikle son 2,5 yıldır Abant Gölü'nde TÜBiTAK'ın desteğiyle yapılan çalışmalar ve analiz sonuçlarına göre bölgede bulunan işletmelerden ve alandaki diğer yapılardan atılan atık sulardan gölü kirlettiği belirlenmiştir. Bu işletmeler arıtma tesislerini sürekli ulanmazlarsa kirlilik, göl ve çevre sularında gelecekte insan sağlığını tehdit edecek boyutlara ulaşacaktır (Çevreye Genç Bakış, 2004). Bu noktadan hareketle göl ve çevresinde meydana gelecek kirlilik kullanıcı memnuniyetinin azalmasına yol açacaktır. Çizelgeye göre memnuniyetsizliği arttıran diğer kriterlerin genelinin kullanıcı bilinçsizliğinden kaynaklandığı belirlenmiştir. Bunun önüne geçilebilmesi için kullanıcıların tutum ve davranışlarını olumlu yönde değiştirecek bilgilendirmeye intiyaç duyulmaktadır.

Roovers ve ark. (2002) göre rekreasyonel aktivitelerin açıklanması için ziyaretçi özellikleri çok önemli değişkenlerdir. Bu çalışmada ziyaretçilerin özelliklerinin, rekreasyon sonucu kullanıcı memnuniyetine etki ettiği saptanmıştır. Çizelge 6'da görüldüğü üzere, Abant Tabiat Parkı'nda genel memnuniyeti en çok etkileyenlerin mevsim, grup büyüklüğü, kullanıcıların cinsiyeti, yaşı, gelir düzeyi ve alana geldikleri yer faktörleri olduğu tespit edilmiştir. Çizelgeye göre Abant Tabiat Parkı'na gelen kullanıcıların alandan en çok sonbahar aylarında memnun kaldıkları tespit edilmiştir. Dolayısıyla özellikle diğer mevsimlerde de kullanıcıların ilgisini çekebilecek aktivitelerin arttırılması ve alanın her mevsim cazip hale getirilmesi gerekmektedir. Alanda kadın ziyaretçilerin erkek ziyaretçilerine göre daha memnun olduğu saptanmıştır. Gelir durumu 0-800 YTL olan ziyaretçiler Abant Tabiat Parkı'ndan en memnun olan kullanıcılardır. Gelir durumu arttıkça memnuniyet azalmakta fakat 1500 YTL'den fazla geliri olan kullanıcıların memnuniyeti tekrar yükselmektedir. Bunun sebebi olarak alanda yüksek gelirli kullanıcı grubuna yönelik olanakların da varlığı gösterilebilmektedir. Alana $100-300 \mathrm{~km}$ arası uzaklıktan gelen kullanıcılar alandan en memnun kullanıcı grubunu oluşturmaktadırlar. Sırasıyla 301 km'den daha uzaktan gelenler ve 0-100 km arasında uzaktan gelenler daha az memnun grubu oluşturmaktadırlar. Buradan hareketle 
alana yakın yerlerden gelen kullanıcılar için belli bir süre sonra alanın cazibesini yitirdiği, kendini yenileyemediği ve memnuniyetin giderek azaldığı sonucu çıkarılabilmektedir. Dolayısıyla alanın sürekli bir cazibe merkezi haline getirilmesi amacıyla gerekli çalışmaların yapılması ve yakın çevrenin kullanımına da yönlendirilmesi gerekmektedir. Alandaki kullanıcılardan 0-25 yaş arası grubun memnuniyetlerinin daha yüksek olduğu gözlenirken, yaşça daha büyük kullanıcı gruplarının memnuniyeti giderek azalmaktadır. Grup büyüklüğü başlığı altında ise yapılan incelemelerde ise, alana organizasyonla gelen kullanıcıların diğerlerine oranla daha az memnun oldukları gözlenmiştir. Buradan hareketle organizasyonlara yönelik aktivitelerde bazı sorunların varlığından bahsedilebilmektedir. Dolayısıyla organizasyona yönelik aktivitelerin daha cazip hale getirilmesi için aksaklıkların tespit edilmesi ve sorunların giderilmesine dair çalışmaların yapılması gerekmektedir.

\section{Kaynaklar}

Absher, J. D., G. Howat, G. Crilley and I Milne. 1996. Toward Quality Customer Service: Market Segments Differences for Sports and Leisure Centres. Australian Leisure, 7(1), 25-28

Atıcı, T., O., Obalı. 2002. Yedigöller ve Abant Gölü (Bolu) Fitoplankton'unun Mevsimsel Değişimi ve Klorifilit-a Değerlerinin Karşılaştırılması. E.Ü. Su Ürünleri Dergisi. Cilt:19. Sayı (3-4):381-389, İzmir.

Brown, P., B. Driver and C. McConnell. 1978. The Opportunity Spectrum Concept in Outdoor Recreation Supply inventories: Background and Application. Proceedings of the Integrated Renewable Resource Inventories Workshop. USDA Forest Service, GTR, RM-55, 73-84

Burns, R. C., A. R. Graefe and J. P. Titre. 1997. Costomer Satisfaction At US Army Corps of Engineers-Administered Lakes: A Compilation of Two Years of Performance Data. Proceedings of the 1997 Northeastern Recreation Research Symposium, USDA Forest Service, GTR, NE -241, 12-13.

Burns, R. C., A. R. Graefe, J. D. Absher and J. Titre. 1998 Water-Based Recreationists' Attitudes Regarding Customer Satisfaction: Differences Between Selected Market Segments. . Proceeding of The 1998 Northeastern Recreation Research Symposium. Northeastern Forest Experiment Station, GTR/NE-255. pp: 166-171

Clark, R. N. And G. H. Stankey. 1979. The Recreation Opportunity Spectrum: A Farmework for Planning, Management and Research. USDA Forest Service, Pasific Northwest Forest and Range Experiment Station, GTR, PNW-98

Çevreye Genç Bakış, 2004. Abant Gölü Elden Gidiyor. Gazi Üniversitesi, Çorum Fen Edebiyat Fakültesi, Çevre ve Doğal Hayat Topluluğu Yayın Organı, Çorum.

Dawson, C. P., R. Oreskes, F. Kaeprznski and T. More. 2001. Visitor Satisfactions: Backcountry and Wilderness Users in the White Mountain National Forest. Froceeding of the 2001 Northeastren Recreation Research Symposium. April 1-3, Bolton Landing, New York.
Driver, B. L. And S. R. Tocher. 1970. Toward a behavioral Interpretation of Recreational Engagements, with Implications for Planning. In B.L. Driver (Ed.) Elements of Outdoor Recretion Planning. Ann Arbor, MI: University Microfilm, pp.9-31

Driver, B. and P. Brown.1978. The Oppurtunity Spectrum Concept and Behavioral İnformation in Outdoor Recreation Resource Supply Inventories: a rationale. İ H. Gyde Lund ve ark. (Tech. Coors.), Proceeding of the Workshop: Integrated Inventories and Renewable Natural Resources. Pp.24-31. Gen. Tech. Rpt. RM-55. USAD, Forest Service. Rocky Mountain Forest and Range Experiment Station. Fort Collins, $\mathrm{CO}$

Driver, B. L., P. J. Brown, G. H. Stankey and T. G. Gregiore. 1987. The ROS planning system: Evolution, basic concepts, and research needed. Leisure Sciences, 9, 201-212.

http://members.fortunecity.com/cerenonen/doğa.html

http://www.kultur.gov.tr/portal/turkiye_tr.asp?belgeno=45702

Mackay, K. J. and J. L. Crampton. 1990. Measuring The Quality Of Recreation Services, Journal of Park and Recreation Administration, 8(3), 47-56.

Mater, B. and H. Sunay. 1985. Abant Gölü Cevresi Turba Oluşumu. I.Ü. Deniz Bilimleri ve Coğrafya Enstitüsü, Istanbul Üniversitesi; Vol:2, No:2; p:77-92, İstanbul

More, T. A., S. Bulmer, L. Henzer and A. E. Mates. 2003. Extending The Recreation Opportunity Spectrum to Nonfederal Lands in the Northeast: An Implementation Guide, US Department of Agriculture, Forest Service, Northeastern Research Station: 1-25. USA.

OBM (Orman Bölge Müdürlüğü), 1991. Abant Tabiat Parkı Özel Amenajman Planı, Bolu.

Parasurman, A., V. A. Zeithaml and L. L. Berry. 1988. SERVQUAL: A Multiple-item Scale for Measuring Consumer Perceptions of Service Quality, Journal of retailing, $64,12-40$

Roovers, P., M. Hermy and H. Gulinck. 2002. Visitor Profile, Perceptions and Expectation in Forests From A Gradient of Increasing Urbanisation in Central Belgium. Landscape and Urban Planing, 59, pp: 129-145

İletişim Adresi:

Haldun MÜDERRisoĞLU

Abant İzet Baysal Üniversitesi

Orman Fakültesi Peyzaj Mimarlığı Bölümü

Konuralp Yerleşkesi / DÜZCE 